\title{
THE
}

\section{Beaver Ponds: Resurgent Nitrogen Sinks for Rural Watersheds in the Northeastern United States}

Julia G. Lazar

University of Rhode Island

Kelly Addy

University of Rhode Island

Arthur J. Gold

University of Rhode Island, agold@uri.edu

Peter M. Groffman

Richard A. McKinney

See next page for additional authors

Follow this and additional works at: https://digitalcommons.uri.edu/nrs_facpubs

\section{Citation/Publisher Attribution}

Lazar, J. G., Addy, K., Gold, A. J., Groffman, P. M., McKinney, R. A., \& Kellogg, D. Q. (2015). Beaver Ponds: Resurgent Nitrogen Sinks for Rural Watersheds in the Northeastern United States. J. Environ. Qual., 44(5), 1684-1693. doi: 10.2134/jeq2014.12.0540

Available at: http://dx.doi.org/10.2134/jeq2014.12.0540

This Article is brought to you for free and open access by the Natural Resources Science at DigitalCommons@URI. It has been accepted for inclusion in Natural Resources Science Faculty Publications by an authorized administrator of DigitalCommons@URI. For more information, please contact digitalcommons-group@uri.edu. 


\section{Authors}

Julia G. Lazar, Kelly Addy, Arthur J. Gold, Peter M. Groffman, Richard A. McKinney, and Dorothy Q. Kellogg

This article is available at DigitalCommons@URI: https://digitalcommons.uri.edu/nrs_facpubs/134 


\title{
Beaver Ponds: Resurgent Nitrogen Sinks for Rural Watersheds in the Northeastern United States
}

\author{
Julia G. Lazar, Kelly Addy, Arthur J. Gold, ${ }^{*}$ Peter M. Groffman, Richard A. McKinney, and Dorothy Q. Kellogg
}

\begin{abstract}
Beaver-created ponds and dams, on the rise in the northeastern United States, reshape headwater stream networks from extensive, free-flowing reaches to complexes of ponds, wetlands, and connecting streams. We examined seasonal and annual rates of nitrate transformations in three beaver ponds in Rhode Island under enriched nitrate-nitrogen $(\mathrm{N})$ conditions through the use of ${ }^{15} \mathrm{~N}$ mass balance techniques on soil core mesocosm incubations. We recovered approximately $93 \%$ of the nitrate $\mathrm{N}$ from our mesocosm incubations. Of the added nitrate $\mathrm{N}, 22$ to $39 \%$ was transformed during the course of the incubation. Denitrification had the highest rates of transformation (97-236 $\mathrm{mg} \mathrm{N} \mathrm{m} \mathrm{d}^{-2} \mathrm{~d}^{-1}$, followed by assimilation into the organic soil $\mathrm{N}$ pool (41-93 $\mathrm{mg} \mathrm{N} \mathrm{m}^{-2} \mathrm{~d}^{-1}$ ) and ammonium generation (11-14 $\mathrm{mg} \mathrm{N} \mathrm{m} \mathrm{N}^{-2} \mathrm{~d}^{-1}$ ). Our denitrification rates exceeded those in several studies of freshwater ponds and wetlands; however, rates in those ecosystems may have been limited by low concentrations of nitrate. Assuming a density of 0.7 beaver ponds $\mathrm{km}^{-2}$ of catchment area, we estimated that in nitrateenriched watersheds, beaver pond denitrification can remove approximately 50 to $450 \mathrm{~kg}$ nitrate $\mathrm{N} \mathrm{km}^{-2}$ catchment area. In rural watersheds of southern New England with high $\mathrm{N}$ loading (i.e., $1000 \mathrm{~kg} \mathrm{~km}^{-2}$ ), denitrification from beaver ponds may remove 5 to $45 \%$ of watershed nitrate $\mathrm{N}$ loading. Beaver ponds represent a relatively new and substantial sink for watershed $\mathrm{N}$ if current beaver populations persist.
\end{abstract}

\section{Core Ideas}

- In rural watersheds of southern New England with high N loading, denitrification from beaver ponds may remove $5-45 \%$ of watershed nitrate-N loading.

- Beaver ponds represent a relatively new, substantial sink for watershed $\mathrm{N}$ if current beaver populations persist.

- Denitrification had the highest rates of nitrate transformation in our beaver pond study, with $\mathrm{N}_{2}$ as the dominant product.

Copyright $\odot 2015$ American Society of Agronomy, Crop Science Society of America, and Soil Science Society of America. 5585 Guilford Rd., Madison, WI 53711 USA. All rights reserved.

J. Environ. Qual. 44:1684-1693 (2015)

doi:10.2134/jeq2014.12.0540

Freely available online through the author-supported open-access option.

Received 17 Dec. 2014.

Accepted 29 May 2015

*Corresponding author (agold@uri.edu).
A NTHROPOGENIC NITROGEN (N) inputs into watersheds have increased in riverine systems (Howarth et al., 1996; Galloway et al., 2004; Han and Allan, 2008), thereby accelerating rates of eutrophication in coastal waters (Turner and Rabalais, 1994). Much effort has been taken to understand and manage $\mathrm{N}$ loads to these aquatic systems to improve water quality and reduce habitat degradation (Galloway et al., 2003). These efforts involve a wide range of approaches including controlling and reducing $\mathrm{N}$ sources, such as fertilizer and sewage, as well as preserving, managing, and restoring $\mathrm{N}$ "sinks," areas where $\mathrm{N}$ is retained or removed from the system, driven by plant, soil, and microbial processes (Davidson et al., 2012).

Recent research has demonstrated that ponds, lakes, and reservoirs can function as significant $\mathrm{N}$ sinks in watersheds (David et al., 2006; Harrison et al., 2009). These water bodies can support reducing conditions that alter the oxidation state of constituents, such as nitrate $\left(\mathrm{NO}_{3}{ }^{-}\right)$and carbon dioxide $\left(\mathrm{CO}_{2}\right)$, influencing nutrient transformations throughout the fluvial network (McClain et al., 2003; Groffman et al., 2005). Reduced conditions are favorable for the removal of waterborne nitrate through denitrification, the microbial transformation of nitrate to $\mathrm{N}$ gases that is perhaps the most important watershed $\mathrm{NO}_{3}{ }^{-}$ removal mechanism (Galloway et al., 2003; Seitzinger et al., 2006, Burgin and Hamilton, 2007) as it removes N completely from the aquatic environment. Similar to other studies, our paper considers denitrification a "sink" for watershed $\mathrm{N}$, even though the nitrate is transformed rather than trapped within the soil or plant biomass (Brezonik and Lee, 1968; Seitzinger, 1988; Mitsch et al., 2001).

The precolonial North American beaver (Castor canadensis) population, estimated between 60 and 400 million, was virtually extirpated in the United States by 1900, primarily due to trapping, but beaver populations rebounded at remarkable rates in the latter half of the 20th century with trapping regulations, lack of predators, and an abundance of forage (Naiman et al., 1988; Baker and Hill, 2003). Whitfield et al. (2015) now estimate the North American beaver population at 30 million. Within the northeastern United States, no beavers existed in Pennsylvania

J.G. Lazar, K. Addy, A.J. Gold, and D.Q. Kellogg, Dep. of Natural Resources Science, Univ. of Rhode Island, One Greenhouse Rd., Kingston, RI 02881; P.M. Groffman, Cary Institute of Ecosystem Studies, Box AB, Millbrook, NY 12545; R.A. McKinney, Atlantic Ecology Division, US Environmental Protection Agency, 27 Tarzwell Dr., Narragansett, RI 02882. Assigned to Associate Editor Amy Townsend-Small.

Abbreviations: DIN, dissolved inorganic nitrogen; DO, dissolved oxygen; DOC, dissolved organic carbon; PTFE, polytetrafluorethlyene. 
by 1915 , but by the first decade of the 21 st century more than 8000 beavers were harvested annually (Hardisky, 2011).

Beaver-created ponds and dams are now reshaping headwater stream networks from extensive, free-flowing reaches to complexes of ponds, wetlands, and connecting streams. These networks slow the flow of stream water and may increase the amount of $\mathrm{N}$ retained or removed at the watershed scale (Saunders and Kalff, 2001; Kellogg et al., 2010). The mechanisms responsible for this $\mathrm{N}$ retention include plant uptake, sedimentation, and the creation of reducing conditions that may promote removal through denitrification (Devito and Dillon, 1993; Naiman et al., 1994; Hill and Duval, 2009). Beaver ponds raise local water tables, which increases the interaction of groundwater with near-surface soils, potentially promoting higher rates of plant uptake of $\mathrm{N}$ and denitrification (Hammerson, 1994; Gold et al., 2001; Hill and Duval, 2009). Beaver ponds also create patches of open water with minimal shade that encourage aquatic plant growth, nutrient uptake, and increased pools of labile organic matter that serve as fuel to denitrifying bacteria in soils (Hammerson, 1994). Published beaver pond sedimentation rates range from less than 1 to $40 \mathrm{~cm} \mathrm{yr}^{-1}$ (Butler and Malanson, 2005). The soil in beaver ponds contains elevated carbon (C) and N, ameliorates stream acidity, and fosters increased anaerobic biogeochemical cycling compared with adjacent fluvial systems (Hammerson, 1994).

In the northeastern United States, beavers are moving into mixed-use watersheds. These watersheds with a mix of agriculture and suburban development often have elevated nitrate levels (Gold et al., 1990; Oakley et al., 2010). The density of beaver ponds in much of the northeastern United States is not likely to approach historic levels as the dams and ponds are often considered a nuisance and beavers are often trapped or moved followed by subsequent dam destruction (Jensen et al., 2001). Even undisturbed beaver ponds tend to be abandoned within several decades due to destruction by extreme flood events and natural beaver migration habits (Gurnell, 1998). Once a pond is abandoned or destroyed, the $\mathrm{N}$ trapped in organic soil materials can be released back into the fluvial network where it can be transformed and transported to coastal waters (Bledzki et al., 2011). It is critical to understand how the larger watershed nutrient dynamics may be altered where these beaver ponds are promoted, as recent work identifying positive ecosystem services of beaver ponds, such as the abatement of dryland streams (Gibson and Olden, 2014), promotion of waterbird communities (Nummi and Holopainen, 2014), and increase in salmon production (Pollock et al., 2004), may spur increased protection or promotion of beaver. Quantifying the extent of $\mathrm{N}$ removal due to denitrification versus storage in soil in these beaver ponds would provide insight into the long-term fate of $\mathrm{N}$ in this recently reintroduced watershed feature.

We measured a number of different nitrate transformation pathways, including denitrification, assimilation into soil microbial biomass and organic $\mathrm{N}$, and the net generation of ammonium $\mathrm{N}$, through the use of mesocosm studies of subaqueous (i.e., below the water) soils from three beaver ponds. This paper specifically examines seasonal and annual rates of nitrate transformations under enriched nitrate conditions to reflect the functions of beaver ponds in mixed use watersheds.

\section{Materials and Methods}

\section{Description of Sites}

We selected three beaver ponds for study based on accessibility and our desire for a range in pond sizes $(0.05-8.00$ ha; Table 1). All sites were located in Washington County, RI; two beaver ponds were located on the Chipuxet River (Ponds A and B), and the final beaver pond was located on Roaring Brook (Pond C). Aerial photos taken every 4 yr from 1976 to 2012 (Univ. of Rhode Island, 2013) showed that the dams and their associated ponds were first constructed within the $4 \mathrm{yr}$ preceding 1988, 1992, and 2008 at ponds C, A, and B, respectively. We found evidence of current beaver activity in all ponds, with beaver lodges and chew marks on freshly cut wood at the dams. Additional site description can be found in Table 1 and Lazar et al. (2014).

\section{Subaqueous Soil Collection}

From a canoe, we collected undisturbed subaqueous soil cores (6 cm diam.; $13 \mathrm{~cm}$ depth) from each pond with a soil corer during fall 2011, spring 2012, and summer 2012. Soil cores were collected in areas of the pond that were unshaded due to either the large size of the pond (Pond C) or the immature woody vegetation on its shoreline (Ponds A and B). The soil corer was a steel rectangular tube $30 \mathrm{~cm}$ long and $7.5 \mathrm{~cm}$ wide. We pushed the coring device into the subaqueous soil to a depth of approximately $20 \mathrm{~cm}$. We immediately pushed a polycarbonate tube $(6 \mathrm{~cm}$ diam.; $13 \mathrm{~cm}$ depth) into the soil core to obtain the cores for the mesocosm experiments. After the soil cores were

Table 1. Site and pond sediment characteristics.

\begin{tabular}{|c|c|c|c|}
\hline Characteristic & $\begin{array}{c}\text { Pond A } \\
\text { (>18 yrt) }\end{array}$ & $\begin{array}{l}\text { Pond B } \\
\text { (>3 yrt) }\end{array}$ & $\begin{array}{c}\text { Pond C } \\
\text { (>23 yrt) }\end{array}$ \\
\hline Latitude; longitude & $41.486175^{\circ} \mathrm{N} ; 71.548384^{\circ} \mathrm{W}$ & $41.503464^{\circ} \mathrm{N} ; 71.533608^{\circ} \mathrm{W}$ & $41.565725^{\circ} \mathrm{N} ; 71.677929^{\circ} \mathrm{W}$ \\
\hline Surface area (ha) & 0.26 & 0.05 & 8.00 \\
\hline Drainage area (ha) & 2450 & 2093 & 976 \\
\hline Tributary name, stream order & Chipuxet, 2 & Chipuxet, 2 & Roaring Brook, 1 \\
\hline First documented evidence (yr) & 1992 & 2008 & 1988 \\
\hline Water depth $(\mathrm{m}) \neq \S$ & $0.93 \pm 0.48$ & $0.59 \pm 0.24$ & $0.75 \pm 0.22$ \\
\hline Thickness of organic soil materials $(\mathrm{m}) \neq$ & $0.29 \pm 0.28$ & $0.66 \pm 0.23$ & $0.45 \pm 0.18$ \\
\hline Mean \% carbon‡ & $17.9 \pm 3.6$ & $16.3 \pm 6.9$ & $30.8 \pm 13.5$ \\
\hline
\end{tabular}

† Minimum age of beaver pond.

$\neq$ Values are mean \pm standard deviation.

$\S$ Water depth was measured in spring 2012.

Journal of Environmental Quality 
collected, they were kept in the tube by sealing the bottom of the core with a plastic cap. Each season we collected 14 cores at random locations within each of the three beaver ponds. We stored five cores at $4^{\circ} \mathrm{C}$ until analysis to obtain "initial" soil conditions. The remaining nine cores were used in the mesocosm experiment and stored in a climate chamber at the pond's ambient water temperature until mesocosm incubations began the next day within $16 \mathrm{~h}$.

Thickness of organic matter was evaluated at a minimum of seven locations in each pond in summer 2013 using a 3-m tile probe and was reported as an average of depth to mineral soil throughout the pond. Water depth was recorded at a minimum of seven locations in each pond at the time of subaqueous soil collection in spring 2012.

Dissolved oxygen (DO) and temperature of the water were measured in each pond when cores were collected. Additionally, we collected $7 \mathrm{~L}$ of pond water on each coring date, subsequently stored in the ambient climate chamber for use in the mesocosm incubations. We filtered a small subsample of pond water from each site and stored it at $4^{\circ} \mathrm{C}$ until analysis of dissolved inorganic nitrogen (DIN), $\mathrm{pH}$, and dissolved organic carbon (DOC).

\section{Mesocosm Incubations}

Our mesocosm chambers, similar to those used in experiments by Seitzinger et al. (1980) and Nowicki (1994), were constructed of two sections of glass-walled pipe $(23.5 \mathrm{~cm}$ height; $7.6 \mathrm{~cm}$ i.d.) joined at the center with an O-ring seal and a metal clamp (Fig. 1). Three glass stopcocks in the upper half of the mesocosms served as ports-one port to add or sample mesocosm water and two ports to add or sample mesocosm headspace gases. We placed the cores, sized to fit the mesocosms, into the lower half of the chambers and immediately added $100 \mathrm{~mL}$ of ambient stream water to each mesocosm to ensure saturation, in case draining occurred in transport and to fill any void space between the core and mesocosm walls. At this point, there was no ponded water above the soil cores.

Each season we assayed a total of 10 mesocosms per pond: 9 with soil cores amended with ${ }^{15} \mathrm{~N}$-nitrate and 1 without a soil core that contained only ${ }^{15} \mathrm{~N}$-nitrate enriched stream water (blank). On the morning after core collection (Day 1), we filled the mesocosms with pond water and incubated them at nearambient $\mathrm{N}$ conditions. After a 4-hr preparation period, we opened the mesocosms to the air and poured off water from the top chamber of each mesocosm.

To prepare for Day 2's incubation under enriched $\mathrm{N}$ conditions, which is the focus of this paper, we added $15 \mathrm{~mL}$ of $100 \mathrm{mg} \mathrm{L}^{-115} \mathrm{~N}$-labeled nitrate $\mathrm{N}$ (50 atom \%) to the top of each of the nine mesocosms based on the ambient nitrate $\mathrm{N}$ levels of the pond to yield approximately 3.3 to $4.0 \mathrm{mg} \mathrm{NO}_{3}^{-} \mathrm{N} \mathrm{L}^{-1}$ at approximately 50 atom $\%$ in the overlying water when the mesocosm was ready for incubation. Ambient pond water (approximately $450 \mathrm{~mL}$ ) from the same pond and collection time as the subaqueous cores was added to each mesocosm to create ponded conditions above the soil cores; note that the mesocosm was sealed the following morning and the final water was pumped in at that point. The blank was treated to yield a similar elevated $\mathrm{N}$ concentration. Mesocosms were left in the dark environmental chamber overnight uncapped at ambient pond temperatures to allow degassing and for the ${ }^{15} \mathrm{~N}$ to disperse into the soil.

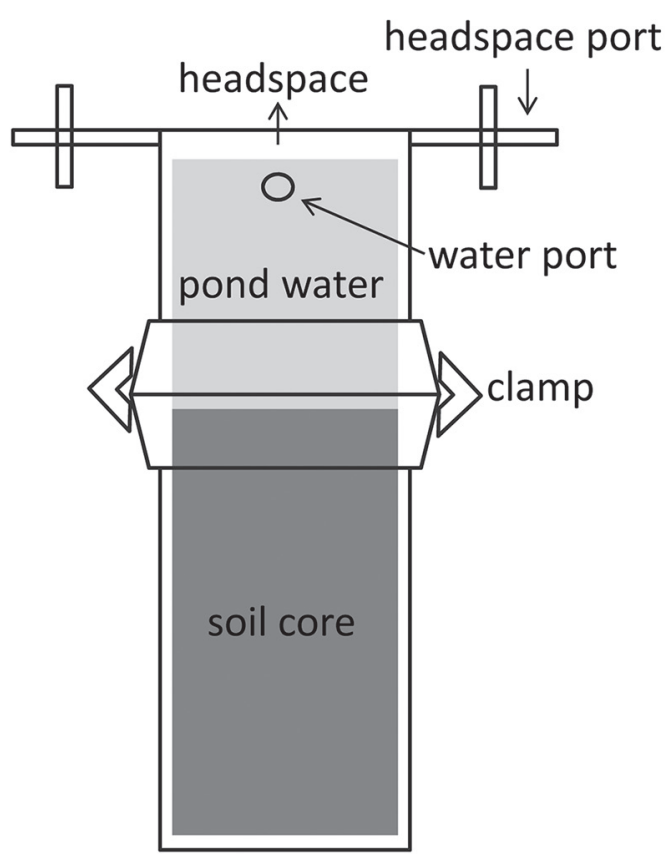

Fig. 1. Soil core incubation mesocosm shown in an illustration (adapted from Nowicki, 1994). The mesocosm consisted of two pieces of glass pipe held together with an 0-ring and metal clamp. Three glass stopcocks were in the top section, one rubber septa was added for sampling the gas phase. An air-driven stirrer was placed on top of the chamber to drive a magnetic stir bar floating in the chamber.

On the following morning (Day 2), we clamped the caps onto the mesocosms. Using a Masterflex L/S portable peristaltic pump (Cole Parmer), we pumped the remainder of the 450 $\mathrm{mL}$ of ambient pond water through a chamber port to fill the mesocosm leaving a $2 \mathrm{~cm}$ headspace at the top to be accessed by the top sampling port to sample headspace gases. To obtain initial $\mathrm{NO}_{3}{ }^{-} \mathrm{N}$ and ammonium $\mathrm{N}\left(\mathrm{NH}_{4}^{+}-\mathrm{N}\right)$ concentrations, $15 \mathrm{~mL}$ of water was removed from each mesocosm via the sampling port, filtered and frozen until analysis. At this point, all port stopcocks were closed, marking the start of the mesocosm incubation experiment. The initial headspace volume was 90 $\mathrm{mL}$ within each mesocosm. When incubation period began, $15 \mathrm{~mL}$ of headspace gas was extracted from each mesocosm for gas analyses. We replaced this headspace with a mix of $80 \%$ helium and 20\% oxygen via a Tedlar bag that was attached to the opposite port. The initial headspace sample was injected into a 12 -mL pre-evacuated Exetainer for later analysis of ${ }^{15} \mathrm{~N}$-enriched gases.

The mesocosms were incubated for $4 \mathrm{~h}$ in the darkened climate chamber under these enriched-N conditions. We stirred each mesocosm hourly with a magnetic stir-bar located at the top of the mesocosm chamber. The stir bar was at the interface between the water surface and headspace; stirring prevented a stagnant boundary layer at the soil-water interface and facilitated equilibration of gases at this interface (Seitzinger et al., 1980). The stirrers were rotated by air-driven magnets mounted on top of each mesocosm (Nowicki, 1994). The blank mesocosms were stirred and sampled as the ${ }^{15} \mathrm{~N}$ core mesocosms. At the end of the incubation, we collected and processed post-incubation water and headspace samples from each mesocosm, as described above. Soil cores were then stored at $4^{\circ} \mathrm{C}$ for further soil analysis. 


\section{Initial and Post-Mesocosm Soil Processing}

Within $2 \mathrm{~h}$ of field collection, subsamples of the five initialcondition soil core samples were weighed and then prepared for drying at $60^{\circ} \mathrm{C}$ for $72 \mathrm{~h}$, after which point the dry mass was measured and percentage soil moisture calculated. Dry bulk density was determined using standard methods (Blake and Hartge, 1986). All initial soil processing values were based on a sample size of five per pond and season, while post-mesocosm soil processing values were based on a sample size of nine per pond and season.

The post-incubation mesocosm soil and the five initialcondition soil cores were processed within $48 \mathrm{~h}$ of the completed mesocosm incubation or initial collection. Each individual soil core was broken apart to remove rocks and coarse wood. The remaining soil was mixed to homogenize the sample. The soil was partitioned into subsamples for analysis of (i) microbial biomass $\mathrm{C}$ and $\mathrm{N}$, (ii) total organic soil $\mathrm{C}$ and $\mathrm{N}$, and (iii) exchangeable DIN $\left(\mathrm{NO}_{3}{ }^{-}-\mathrm{N}\right.$ and $\left.\mathrm{NH}_{4}^{+}{ }^{+} \mathrm{N}\right)$.

Soil microbial biomass was determined using a rapid chloroform-fumigation extraction technique (Witt et al., 2000) followed by extraction of DIN by $0.5 \mathrm{M} \mathrm{K}_{2} \mathrm{SO}_{4}$ (Mulvaney, 1996; Mulvaney, 2008). Microbial C and $\mathrm{N}$ were calculated as the difference in extractable fractions between the fumigated and unfumigated soil (Witt et al., 2000). These extracts were filtered and frozen until DIN analysis and further diffusion techniques. Microbial biomass extracts were prepared for ${ }^{15} \mathrm{~N}$ analysis using the 6-d polytetrafluorethlyene (PTFE) tape diffusion method in a jar (Sorensen and Jensen, 1991; Stark and Hart, 1996; Sigman et al., 1997) where $\mathrm{NH}_{4}^{+}$in the extract was converted to $\mathrm{NH}_{3}$ gas, which was diffused onto the filter traps between two pieces of PTFE tape. Following the 6- $\mathrm{d} \mathrm{NH}_{4}^{+}$diffusion, the filter traps were removed from the jar, put into a dessicator to dry, and later packed into tins for analysis of ${ }^{15} \mathrm{~N}$ from the ammonium pool. Devarda's alloy was then added to each jar along with a new filter trap within PTFE tape and incubated for another $6 \mathrm{~d}$ to convert $\mathrm{NO}_{3}{ }^{-}$to $\mathrm{NH}_{4}^{+}$, which was then converted to $\mathrm{NH}_{3}$ gas. Then this filter trap was removed, dried, and packed into tins for analysis of ${ }^{15} \mathrm{~N}$ from the nitrate pool.

For analysis of organic soil $\mathrm{C}$ and $\mathrm{N}$, soil was dried and ground through a size 10 sieve. A small subsample (5-8 mg) of each initial and post-mesocosm core that passed through the sieve was weighed into a tin capsule and stored in a desiccator until analysis of $\mathrm{C}$ and $\mathrm{N}$ concentration and ${ }^{15} \mathrm{~N}$ determination.

To extract the exchangeable DIN content, dried soil was incubated with $0.5 \mathrm{M} \mathrm{K}_{2} \mathrm{SO}_{4}$ (Mulvaney, 1996, 2008) followed by filtering and freezing until DIN analysis or further diffusion techniques as described above to determine the ${ }^{15} \mathrm{~N}$ associated with nitrate $\mathrm{N}$ and ammonium $\mathrm{N}$.

\section{Denitrification Rates}

Denitrification rates were determined through the comparison of initial versus final headspace samples that quantified the amount of ${ }^{15} \mathrm{~N}_{2}$ and ${ }^{15} \mathrm{~N}-\mathrm{N}_{2} \mathrm{O}$ generated over the 4-h incubation time in the enriched $\mathrm{N}$ mesocosm conditions ( $n=9$ per pond and season). Denitrification masses of $\mathrm{N}_{2} \mathrm{O}-\mathrm{N}$ and $\mathrm{N}_{2}$ gases $(\mu \mathrm{mol})$ in headspace samples were calculated using the headspace equilibration method (Tiedje, 1982) and then divided by the respective ${ }^{15} \mathrm{~N}$ sample enrichment. The mass of
${ }^{15} \mathrm{~N}_{2} \mathrm{O}-\mathrm{N}$ or ${ }^{15} \mathrm{~N}_{2}$ generated during the incubation period was calculated as the mass in the final samples minus the mass in the initial samples. The total masses of $\mathrm{N}_{2} \mathrm{O}-\mathrm{N}$ and $\mathrm{N}_{2}-\mathrm{N}$ produced were calculated by dividing the masses of ${ }^{15} \mathrm{~N}_{2} \mathrm{O}-\mathrm{N}$ and ${ }^{15} \mathrm{~N}_{2}$ by the starting ${ }^{15} \mathrm{~N}$ isotope enrichment of the mesocosm. The mass of $\mathrm{N}_{2} \mathrm{O}-\mathrm{N}$ and $\mathrm{N}_{2}$ generated was then expressed per surface area of pond soil by dividing by the surface area of the mesocosm and the 4-h closed chamber incubation period to yield gas production rates $\left(\mathrm{N}_{2} \mathrm{O}-\mathrm{N}\right.$ and $\left.\mathrm{N}_{2}\right)$ of $\mathrm{mg} \mathrm{N} \mathrm{m} \mathrm{N}^{-2}$ soil $\mathrm{h}^{-1}$. The computed rates represent denitrification capacity-how much denitrification could occur if ample nitrate was present per the nitrate additions under pond soil conditions, including electron donor, temperature, or redox conditions (Addy et al., 2005).

\section{Organic and Inorganic Nitrogen Rates}

Assimilation into organic soil $\mathrm{N}$ was calculated as the difference between the mean initial ( $n=5$ per pond and season) and the mean post-incubation organic ${ }^{15} \mathrm{~N}$-labeled nitrogen $(n$ $=9$ per pond and season) in the soil. Ammonium $\mathrm{N}$ generation rates were calculated from the difference between the mean initial ( $n=5$ per pond and season) and the mean post-incubation ${ }^{15} \mathrm{~N}$ labeled ammonium $\mathrm{N}$ ( $n=9$ per pond and season). We divided these differences by the mesocosm surface area and the $24 \mathrm{~h}$ period under enriched $\mathrm{N}$ conditions.

\section{Nitrate-N Recoveries}

The nitrate $\mathrm{N}$ pools ( $n=9$ per pond and season) that we quantified after enriched conditions in this study are:

1. Initial mass of nitrate $\mathrm{N}\left(\mathrm{NO}_{3}{ }^{-}-\mathrm{N}^{\mathrm{i}}\right)$ at incubation period commencement. $\mathrm{NO}_{3}{ }^{-}-\mathrm{N}^{\mathrm{i}}$ was computed from its mass within the exchangeable DIN in initial soil plus the total mass of $\mathrm{NO}_{3}{ }^{-}-\mathrm{N}$ additions and the ambient $\mathrm{NO}_{3}{ }^{-} \mathrm{N}$ in the pond water additions to the mesocosms.

2. Nitrate-N that was transformed $\left(\mathrm{NO}_{3}{ }^{-}-\mathrm{N}^{\mathrm{t}}\right)$ via denitrification, assimilation into the soil organic $\mathrm{N}$ pool, and $\mathrm{NH}_{4}^{+}-\mathrm{N}$ generation, all by tracing ${ }^{15} \mathrm{~N}$ signatures.

3. Nitrate- $\mathrm{N}$ that remained in the exchangeable DIN at the conclusion of the experiment $\left(\mathrm{NO}_{3}{ }^{-}-\mathrm{N}^{\mathrm{ex}}\right)$, and

4. Nitrate- $\mathrm{N}$ that was poured off with the overlying water before the enriched nitrate mesocosm incubation period $\left(\mathrm{NO}_{3}{ }^{-}-\mathrm{NP}\right)$.

Based on this mass-balance approach, total nitrate $\mathrm{N}$ recovered under enriched conditions is

$$
\frac{\left(\mathrm{NO}_{3}{ }^{-}-\mathrm{N}^{\mathrm{t}}+\mathrm{NO}_{3}{ }^{-}-\mathrm{N}^{\mathrm{ex}}+\mathrm{NO}_{3}{ }^{-}-\mathrm{N}^{\mathrm{P}}\right)}{\mathrm{NO}_{3}{ }^{-}-\mathrm{N}^{\mathrm{i}}}
$$

\section{Analytical Methods}

The University of California-Davis Stable Isotope Facility analyzed the mesocosm headspace samples for concentrations and isotope ratios of $\mathrm{N}_{2}$ and $\mathrm{N}_{2} \mathrm{O}$ using a ThermoFinnigan GasBench + PreCon trace gas concentration system interfaced to a ThermoScientific Delta V Plus isotope-ratio mass spectrometer.

We analyzed soil samples for $\mathrm{N}$ and $\mathrm{C}$ isotope composition using continuous flow isotope ratio mass spectrometry utilizing a Vario Micro Elemental Analyzer interfaced to a Elementar Isoprime 100 Mass Spectrometer (Elementar Americas). The N 
isotopic composition is expressed as a part per thousand (permil) difference from the composition of a recognized reference material, which by convention, is $\mathrm{N}_{2}$ in air (Mariotti, 1983). All samples were analyzed in duplicate with a typical difference of approximately $0.1 \%$.

We measured DIN concentrations in soil extracts and water samples using an Astoria Pacific Model 303A Segmented Continuous Flow Autoanalyzer (Astoria-Pacific Inc.). The open tubular cadmium reduction method $\left(4500-\mathrm{NO}_{3}{ }^{-}\right.$; Eaton et al., 1998) was used for $\mathrm{NO}_{3}{ }^{-}-\mathrm{N}$. The automated phenate method (4500- $\mathrm{NH}_{3}$; Eaton et al., 1998) was used for $\mathrm{NH}_{4}^{+}$N. Laboratory procedures followed the accuracy and precision assessments described by Green (2009).

Fumigated and unfumigated soil extracts were analyzed for DOC using a Shimadzu Total Organic Carbon Analyzer. Dissolved oxygen and temperature were measured in the field using a YSI DO-temperature meter, model 55. At the end of the incubation, DO was measured using the azide modification method (4500-O; Eaton et al., 1998). pH was measured on an Accument Research AR20 pH/conductivity meter.

\section{Statistical Analyses}

We tested for differences between site and season using twoway analysis of variance (ANOVA) for the following variables: denitrification, net generation of ammonium $\mathrm{N}$, nitrate assimilation into soil organic $\mathrm{N}$, and soil microbial biomass $\mathrm{C}$ and $\mathrm{N}$. We then used a Tukey's post-hoc test if significant interactions were detected. If we did not find significant interactions between site and season, we completed a one-way ANOVA on the above variables with a Tukey's post-hoc test. After determining the effect of site and season on $\mathrm{N}$ cycling, we ran a series of $t$ tests to determine if there was a significant difference between the overall $\mathrm{N}$ cycling rates.

We evaluated correlations between denitrification rates and $\log$ transformed $\mathrm{N}_{2} \mathrm{O}: \mathrm{N}_{2}$ data using Pearson productmoment correlation coefficients. The Pearson product-moment correlation procedure tested correlative relationships between nitrate processing rates (denitrification, assimilation into soil organic $\mathrm{N}$, and ammonium generation) and mean percentage $\mathrm{C}$, DO saturation, temperature, DOC, $\mathrm{pH}$, and nitrate concentration. Statistical significance was set at $\alpha<0.05$ for all analyses. All statistics were performed using Statistica (StatSoft, Inc., 2013).

\section{Results}

\section{Soil and Water Characteristics}

Pond $\mathrm{B}$ had the shallowest water and thickest organic soils (Table 1). Percentage soil moisture within the soil cores ranged from 70 to $90 \%$, with an average of $79 \%$. Across all sites and seasons, average dry bulk density was $0.33 \mathrm{~g} \mathrm{~cm}^{-3}$. These soils are classified organic soils based on percentage C (Table 1; Fanning and Fanning, 1989). Pond $\mathrm{C}$ had slightly more acidic soil with a soil $\mathrm{pH}$ of 5.5, compared with 6.3 and 6.0 in Ponds $\mathrm{A}$ and $B$, respectively. The thickness of organic soil materials ranged from $0.29 \mathrm{~m}$ in Pond A to $0.66 \mathrm{~m}$ in Pond B (Table 1). Based on a two-way ANOVA, there were no interactions of site and season for soil microbial biomass $\mathrm{C}$. Soil microbial biomass $\mathrm{C}$ did not vary significantly between ponds $(F=0.2$, df $=2)$ but was significantly different between seasons $(F=39.70, \mathrm{df}=2 ; p$ $<0.001)$. Based on the Tukey's post-hoc test $(\mathrm{df}=78 ; p<0.001)$, spring displayed significantly higher values (mean: $188 \mathrm{mg} \mathrm{C}$ $\mathrm{kg}^{-1}$ dry soil; SD: 84) than summer or fall (96 and $17 \mathrm{mg} \mathrm{C} \mathrm{kg}{ }^{-1}$ dry soil, respectively).

Based on field-measured data, DO and temperature changed with the seasons, with summer being the warmest and having the lowest DO (Table 2). Concentrations of DO in the mesocosms ranged from 5 to $8 \mathrm{mg} \mathrm{L}^{-1}$ throughout all mesocosm incubations. In situ DOC ranged from 3.9 to $5.2 \mathrm{mg} \mathrm{L}^{-1}$ between sites and seasons (Table 2). Pond water $\mathrm{pH}$ was fairly stable across sites and seasons (range: 5.9-6.4; Table 2). Pond $C$ always had the lowest nitrate concentration - at our no detect level $(0.02 \mathrm{mg}$ $\mathrm{N} \mathrm{L}^{-1}$ ) or slightly above (Table 2 ). Pond A had elevated nitrate levels in spring and summer, whereas Pond B had elevated nitrate levels in spring only (Table 2).

\section{Nitrate Recovery}

The nitrate $\mathrm{N}$ recovery under enriched conditions, based on the fate of ${ }^{15} \mathrm{~N}$-labeled nitrate via denitrification, assimilation into organic soil $\mathrm{N}$, and ammonium $\mathrm{N}$ generation (collectively $\left.\mathrm{NO}_{3}{ }^{-}-\mathrm{N}^{\mathrm{t}}\right)$, changes in nitrate $\left(\mathrm{NO}_{3}{ }^{-}-\mathrm{N}^{\mathrm{ex}}\right)$, and the nitrate in the water overlying the soil $\left(\mathrm{NO}_{3}{ }^{-}{ }^{-} \mathrm{N}\right)$, averaged 93\% (SD: 13.8).

Table 2. Pond water characteristics on core collection dates for Pond A ( $>18 \mathrm{yr}$ old), Pond B ( $>3 \mathrm{yr}$ old), and Pond C ( $>23 \mathrm{yr}$ old).

\begin{tabular}{|c|c|c|c|c|c|c|}
\hline Characteristic & Dissolved oxygen & Dissolved oxygen & Water temperature & Dissolved organic C & $\mathrm{pH}$ & Nitrate \\
\hline & $\mathrm{mg} \mathrm{L}^{-1}$ & $\%$ saturation & ${ }^{\circ} \mathrm{C}$ & $\mathrm{mg} \mathrm{L}^{-1}$ & & $\mathrm{mg} \mathrm{N} \mathrm{L}^{-}$ \\
\hline \multicolumn{7}{|c|}{ Fall } \\
\hline Pond A & 4.8 & 42 & 8.8 & 3.9 & 6.3 & 0.21 \\
\hline Pond B & 6.3 & 55 & 9.3 & 4.5 & 6.2 & 0.30 \\
\hline Pond C & 4.6 & 42 & 10.6 & 5.0 & 5.9 & 0.02 \\
\hline \multicolumn{7}{|c|}{ Spring } \\
\hline Pond A & 8.1 & 82 & 16.4 & 4.7 & 6.4 & 0.98 \\
\hline Pond B & 8.9 & 88 & 15.1 & 5.2 & 6.3 & 0.90 \\
\hline Pond C & 7.2 & 73 & 16.4 & 5.0 & 6.0 & 0.05 \\
\hline \multicolumn{7}{|c|}{ Summer } \\
\hline Pond A & 3.1 & 38 & 26.4 & 5.6 & 6.2 & 0.90 \\
\hline Pond B & 3.7 & 46 & 25.5 & 4.0 & 6.2 & 0.25 \\
\hline Pond C & 4.8 & 58 & 25.2 & 4.6 & 6.1 & $\mathrm{nd}+$ \\
\hline
\end{tabular}

† nd, no detect, below our detection limit of $0.02 \mathrm{mg} \mathrm{N} \mathrm{L}^{-1}$. 
Of the nitrate $\mathrm{N}$ that we added, 22 to $39 \%$ was transformed during the course of the incubation.

\section{Denitrification}

Denitrification was the process with the highest nitrate transformation rates during all seasons and in all the ponds. As the mesocosm experiments were completed under enriched conditions, these rates represent denitrification capacity rates. Interactions were observed between sites and season $(F=2.5$; $\mathrm{df}=4 ; p<0.05$ ) for denitrification rates in a two-way ANOVA. There was significant $(p<0.001)$ variation in denitrification with season $(F=21.5$; $\mathrm{df}=2)$ and site $(F=11.3$; $\mathrm{df}=2)$. We conducted post-hoc Tukey tests $(p<0.05)$ to determine the significance within site and season. Spring had significantly lower denitrification rates than summer or fall (Fig. 2a). Pond $\mathrm{C}$, the oldest and largest beaver pond, which also had the lowest ambient $\mathrm{NO}_{3}-\mathrm{N}$ concentrations, had significantly lower denitrification rates than Pond $\mathrm{B}$, the newest and smallest beaver pond (Fig. 2b). Nitrogen gas made up the majority of the denitrification gases. The mean $\mathrm{N}_{2} \mathrm{O} / \mathrm{N}_{2}$ ratio across all sites and seasons was 0.12. Log transformed $\mathrm{N}_{2} \mathrm{O} / \mathrm{N}_{2}$ was negatively correlated with denitrification $\left(r^{2}=0.18 ; p=0.001\right)$. Denitrification was negatively correlated with pond DO saturation $\left(r^{2}=0.52 ; p<0.05\right)$; no other significant relationships
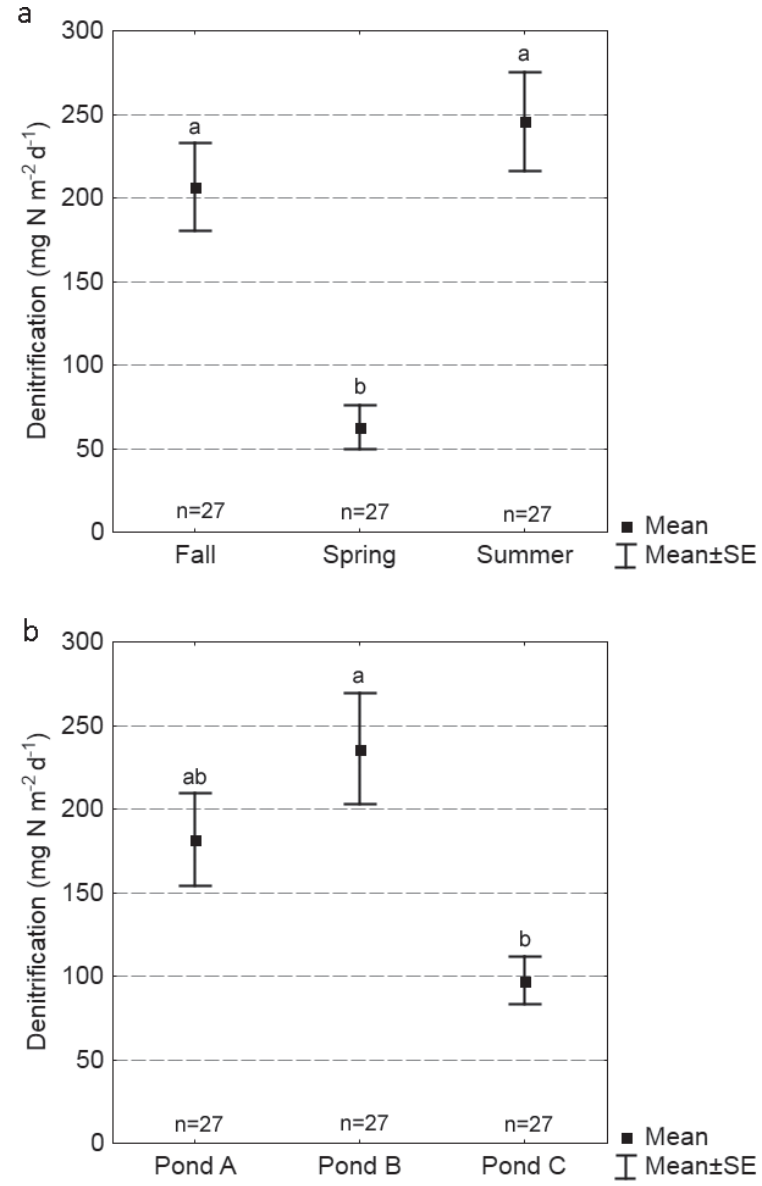

Fig. 2. Denitrification rates from three beaver pond soil core mesocosm incubations by (a) season $(n=27)$ and (b) site $(n=27)$. Squares are mean rates with standard error bars. Different letters within a plot indicate significant differences by a Tukey's post-hoc mean separation test following a two-way analysis of variance (season and site). with pond characteristics were observed. Denitrification in the blank mesocosms was negligible.

\section{Organic Soil Nitrogen Assimilation}

Rates of assimilation into the organic soil $\mathrm{N}$ pool were significantly lower than transformation rates associated with denitrification $(t=-2.7$; $\mathrm{df}=16 ; p<0.05)$. We observed no significant interactions between site and season for assimilation into organic soil $\mathrm{N}$ pool in a two-way ANOVA. In a one-way ANOVA, the rate of nitrate $\mathrm{N}$ transformation into soil organic $\mathrm{N}$ pool was not significantly different by season (Fig. 3a; $F=0.1$; $\mathrm{df}=2$ ), but was significantly different based on sites (Fig. 3b; $F=$ $7.0, \mathrm{df}=2 ; p<0.001)$. With a post-hoc Tukey test, Pond B had a significantly lower assimilation into the soil organic $\mathrm{N}$ pool than the other two ponds $(p<0.05)$. Rates of assimilation into the organic soil $\mathrm{N}$ pool were not significantly correlated with pond characteristics.

Per our soil assay, rates of microbial biomass $\mathrm{N}$ constituted 5 to $20 \%$ of the rate of assimilation to organic soil $\mathrm{N}$. There were significant interactions between site and season for microbial biomass $\mathrm{N}(\mathrm{df}=4 ; p<0.01)$ in a two-way ANOVA. The rate of nitrate transformation to microbial biomass $\mathrm{N}$ was found to be significantly different by site $(F=4.89$; $\mathrm{df}=2 ; p<0.05)$ and season $(F=3.35$; $p<0.05)$. In a post-hoc Tukey test, Pond $C$ had significantly higher microbial biomass $\mathrm{N}\left(15 \mathrm{mg} \mathrm{N} \mathrm{m}^{-2} \mathrm{~d}^{-1}\right)$
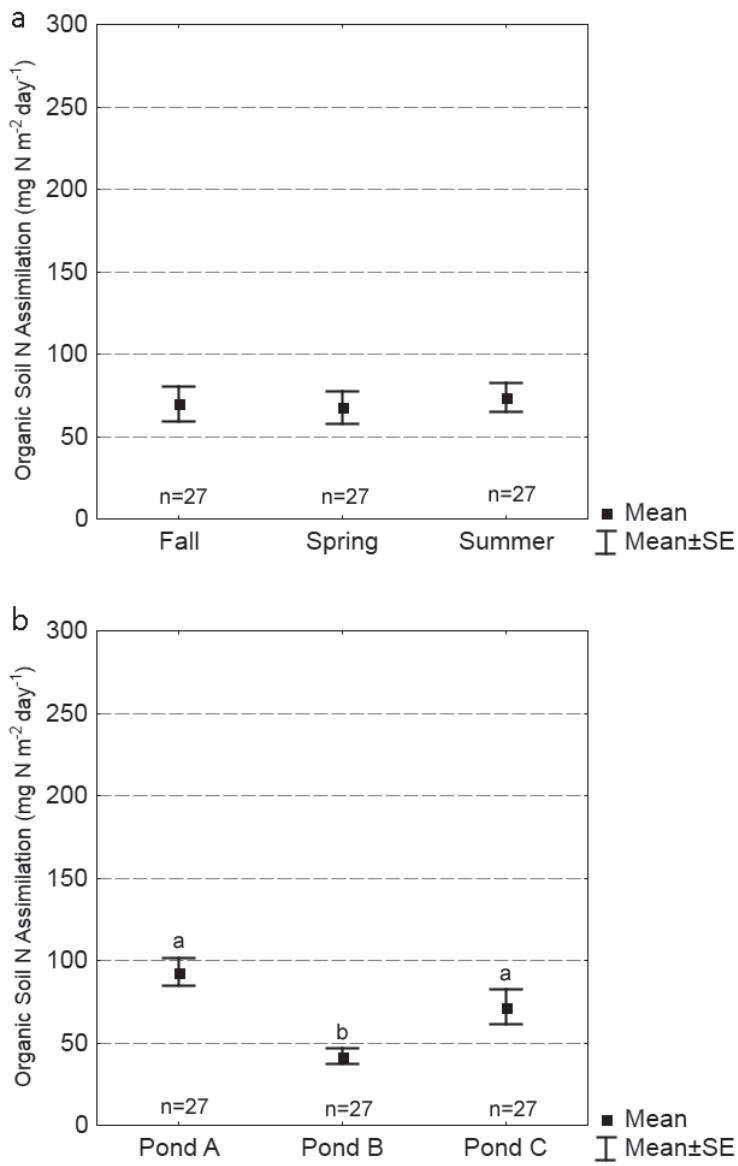

Fig. 3. Assimilation rates into organic soil nitrogen from three beaver pond soil core mesocosm incubations by (a) season $(n=27)$ and (b) site $(n=27)$. Squares are mean rates with standard error bars. Different letters within a plot indicate significant differences by a Tukey's post-hoc mean separation test following a two-way analysis of variance (season and site). 
than Pond $\mathrm{A}$ or $\mathrm{B}$ ( 5 and $6 \mathrm{mg} \mathrm{N} \mathrm{m}^{-2} \mathrm{~d}^{-1}$, respectively; $p<0.01$ ). No significant differences in microbial biomass $\mathrm{N}$ were observed between seasons with the post-hoc Tukey test.

\section{Ammonium N Generation}

Ammonium generation rates were significantly lower than transformations associated with denitrification $(t=-4.3, \mathrm{df}=$ $8, p<0.01)$ and assimilation into soil organic $\mathrm{N}(t=-6.0, \mathrm{df}$ $=8, p<0.01)$. There were significant interactions between site and season for ammonium generation rates $(F=3.1$; $\mathrm{df}=4$; $p<0.05)$ in a two-way ANOVA. Rates were not significantly different when comparing sites $(F=0.8$; df $=2)$ or season $(F$ $=0.7 ; \mathrm{df}=2)$. Overall mean net ammonium $\mathrm{N}$ generation rate across all sites and seasons was $6.4 \mathrm{mg} \mathrm{N} \mathrm{m}^{-2} \mathrm{~d}^{-1}$ (SD: 5.3). Rates of ammonium generation were not significantly correlated with pond characteristics.

\section{Discussion}

We used a mass-balance approach based on ${ }^{15} \mathrm{~N}$ tracer additions to soil core mesocosm incubations to examine the fate of nitrate in beaver ponds and the capacity of these systems to serve as watershed $\mathrm{N}$ sinks. Similar mesocosms have been used in the past by Seitzinger et al. (1980) and Nowicki (1994) to assess $\mathrm{N}$ transformations in subaqueous soils. The mesocosm approach enables a suite of processes in both water and soil to be examined simultaneously in replicated samples (Oviatt and Gold, 2005; Fulweiler et al., 2007). Past ${ }^{15} \mathrm{~N}$ experiments have studied the effects of $\mathrm{N}$ inputs on $\mathrm{N}$ retention and mobility, addressing questions such as microbial uptake, plant-microbial competition for $\mathrm{N}$, and links to C cycling (Tietema et al., 1998; Currie et al., 1999; Nadelhoffer et al., 1999). The use of the stable isotope ${ }^{15} \mathrm{~N}$ as a tracer has provided important insights into the fluxes and transformations of $\mathrm{N}$ in soils and at the ecosystem level (Stark and Hart, 1997; Tietema et al., 1998, respectively).

We were able to account for a high proportion of the nitrate $\mathrm{N}$ in the mesocosms. Deviations from complete recovery of nitrate $\mathrm{N}$ may have partially resulted from nitrification within the mesocosms or from intracore variations between the replicate mesocosms.

\section{Factors Controlling Soil Nitrate Transformation}

Subaqueous beaver pond soils displayed high rates of nitrate transformations at all sites and during all seasons, suggesting that these ecosystems can serve as substantial sinks for watershed nitrate. Our denitrification rates were comparable to those noted in a number of other studies on freshwater ponds and constructed wetlands (Table 3) and greater than those reported for streams by Mulholland et al. (2008). Our values exceeded those observed in some studies of freshwater ponds and wetlands (Table 3); however, rates in the other studies may have been limited by low concentrations of nitrate. Pond C, which is the oldest pond and is dominated by deeper open water and less coverage by emergent vegetation, had significantly lower denitrification rates than Pond B, which was at the opposite end of the spectrum being the youngest, smallest pond with more emergent vegetation. This trend agrees with previous studies that demonstrated that young wetlands with emergent macrophyte vegetation have higher denitrification potential than open water wetlands (Anderson et al., 2005; Hernandez and Mitsch, 2007).

As expected, a significantly negative correlation with denitrification and percentage oxygen saturation of the pond water column was observed. No other significant correlates of the nitrogen processing patterns were observed.

We observed significant seasonal patterns, with lower denitrification rates in spring. Soil microbial biomass C was higher in the spring, suggesting that high rates of immobilization may have been competing with denitrification during spring. The beaver pond soil had levels of microbial biomass $\mathrm{C}$ comparable to other wetlands (Nguyen, 2000; Tietz et al., 2007).

Although nitrate assimilation into soil organic $\mathrm{N}$ pools was the second-largest ecosystem sink for added nitrate, this assimilation into microbial biomass and/or soil organic $\mathrm{N}$ may not represent a long-term sink, increasing the importance of the measured denitrification rates as a more permanent nitrate removal mechanism. The observed assimilation rates may be the result of abiotic uptake of nitrate that is not considered to be biological immobilization (Davidson et al., 1991; Fitzhugh et al., 2003; Colman et al., 2008). There is much debate in the literature about how this process happens. Two common hypotheses are (i) that it is an analytical artifact (Colman et al., 2007,2008 ) and (ii) that the iron in the system interferes with nitrite and forms organic $\mathrm{N}$ in the "ferrous wheel hypothesis" (Davidson et al., 2003, 2008).

Net ammonium $\mathrm{N}$ generation may result from rapid immobilization followed by mineralization or from dissimilatory nitrate reduction to ammonium (DNRA), a microbially mediated pathway involving the transformation of nitrate to ammonium. The eventual fate of the nitrate converted to

Table 3. Denitrification rates in comparison to other studies of shallow ponds, meadows and wetlands.

\begin{tabular}{|c|c|c|c|}
\hline Study & Setting & Denitrification & Method \\
\hline & & $\mathrm{mg} \mathrm{N} \mathrm{m}^{-2} \mathrm{~d}^{-1}$ & \\
\hline Naiman et al., 1994 & beaver pond & 2.0 & Acetylene block technique \\
\hline Naiman et al., 1994 & wet meadow & 2.6 & Acetylene block technique \\
\hline Batson et al., 2012 & constructed wetland & 3.4 & Acetylene block technique \\
\hline Song et al., 2012 & constructed wetland & $0.8-15.8$ & Acetylene block technique \\
\hline Bonnett et al., 2013 & wetland & 17.9 & Acetylene block technique \\
\hline Scott et al., 2008 & constructed wetland & 16.8 & Net $\mathrm{N}_{2}$ flux \\
\hline This study & beaver ponds & $97-236$ & ${ }^{15} \mathrm{~N}$ tracer technique \\
\hline Xue et al., 1999 & constructed wetland & $48-283$ & Acetylene block technique \\
\hline Xue et al., 1999 & constructed wetland & $48-223$ & ${ }^{15} \mathrm{~N}$ tracer technique \\
\hline Vecherskiy et al., 2011 & beaver pond & 266 & Acetylene block technique \\
\hline David et al., 2006 & reservoir in agricultural landscape & $170-616$ & Acetylene block technique \\
\hline
\end{tabular}


ammonium is unknown, but it does not represent permanent $\mathrm{N}$ removal from the aquatic ecosystem as it may be converted back to nitrate via nitrification or assimilated into biomass (Burgin and Hamilton, 2007), and we note that it was a relatively small sink in our study compared with the other nitrate transformation pathways.

\section{Nitrous 0xide Source?}

Nitrous oxide to nitrogen gas ratios were negatively correlated to denitrification rates. This ratio has been shown to be controlled by a number of factors, including oxygen saturation, $\mathrm{pH}$, soil moisture and nitrate loading, but there remains considerable uncertainty in these relationships (Knowles, 1981; Seitzinger, 1988; Groffman et al., 2002; Beaulieu et al., 2011). All of our soils were saturated and had similar $\mathrm{pH}$ levels and nitrate concentrations. Our data suggest that under enriched conditions, beaver ponds have greater $\mathrm{N}_{2} \mathrm{O}$ production $(12 \%$ of $\mathrm{N}$ gas generation) than the 53 streams assessed by Beaulieu et al. (2011), which generated only 0.04 to $5.5 \%$ as $\mathrm{N}_{2} \mathrm{O}$. Our $\mathrm{N}_{2} \mathrm{O}$ generation data were also higher than those found in a synthesis of literature values in wetland soils (Schlesinger, 2009), which had an average $\mathrm{N}_{2} \mathrm{O}$ yield of $8.2 \%$. However, in a companion study, Lazar et al. (2014) found much lower $\mathrm{N}_{2} \mathrm{O}$ production in these same beaver ponds with floating gas chambers. We suspect we may have disrupted the $\mathrm{N}_{2} \mathrm{O} / \mathrm{N}_{2}$ ratio observed in situ by introducing more oxygenated pond water into what is expected to be more anoxic sediment-water interface as the ratio of $\mathrm{N}_{2} \mathrm{O}$ / $\mathrm{N}_{2}$ in denitrification declines with declining oxygen availability (Knowles, 1981; Carlton and Wetzel, 1988). $\mathrm{N}_{2} \mathrm{O}$ production could also be the result of nitrification of ammonium (Wrage et al., 2001), but our methods did not enable us to track this pathway.

When considering beaver on the landscape, land managers need to carefully weigh the ecosystem services versus ecosystem disservices. Ecosystem services may include the abatement of dryland streams (Gibson and Olden, 2014), promotion of waterbird communities (Nummi and Holopainen, 2014), increase in salmon production (Pollock et al., 2004), and the removal of reactive $\mathrm{N}$ from the watershed as discussed herein. Ecosystem disservices may include increased greenhouse gas emissions (Lazar et al., 2014; Whitfield et al., 2015). Further fieldwork that measures $\mathrm{N}_{2} \mathrm{O}$ flux from beaver ponds in mixed use watersheds may be warranted to determine their significance as $\mathrm{N}_{2} \mathrm{O}$ sources.

\section{Estimating Watershed Sink Capabilities of Beaver Ponds}

To provide insight into the potential role of beaver ponds on the export of nitrate $\mathrm{N}$ from small catchments, we linked annual estimates of beaver pond denitrification capacity rates derived from our mesocosm study with estimates of watershed nitrate inputs and the ratio of catchment area to beaver pond area in the study region. We did not include nitrate removal due to immobilization since beaver ponds are transient and the stored organic deposits can be released and mineralized when the pond is destroyed (Bledzki et al., 2011). The annual rate under enriched conditions was computed by extrapolating measured seasonal rates over $273 \mathrm{~d}$ to represent the spring through fall seasons when we obtained measurements, with the assumption that denitrification would be negligible during winter due to low temperatures and reduced inflows. Given the likelihood that some denitrification will occur over the winter months, this assumption generated a conservative estimate of annual denitrification capacity.

We assumed 0.7 beaver ponds $\mathrm{km}^{-2}$ of catchment area based on studies conducted in southern New England (DeStefano et al., 2006). Beaver pond area can be quite variable-our three pond areas displayed a range of more than two orders of magnitudedue to factors such as physiography and age of pond. To capture the range of pond areas, we used both the median beaver pond area ( $0.26 \mathrm{ha})$ from our three sites and a pond area of 1.0 ha, which represents a minimum size from many other studies (Weyhenmeyer, 1999; Pollock et al., 2003).

Using the annual range of denitrification observed in our three ponds, we estimate that denitrification in beaver ponds that average 0.26 ha can annually remove 49 to $118 \mathrm{~kg}$ nitrate $\mathrm{N} \mathrm{km}^{-2}$ of catchment area. In beaver ponds that average 1 ha, denitrification can account for 187 to $454 \mathrm{~kg}$ nitrate $\mathrm{N} \mathrm{km}^{-2}$ of catchment area. Moore et al. (2004), using the SPARROW model, predicted total $\mathrm{N}$ catchment yields between 200 and $1000 \mathrm{~kg} \mathrm{~km}^{-2}$ for undeveloped land uses (i.e., rural) in southern New England. Based on the beaver pond/watershed area ratios $(0.18-0.7 \%)$, and interpond variability in denitrification, we estimate that beaver ponds in southern New England can remove 5 to $45 \%$ of watershed nitrate loading from rural watersheds with high $\mathrm{N}$ loading (i.e., $1000 \mathrm{~kg} \mathrm{~km}^{-2}$ ). Thus, beaver ponds represent an important sink for watershed nitrate if current beaver populations persist.

\section{Acknowledgments}

We thank undergraduates Molly Welsh, Mary Nicole Gutierrez, Jill Raval, Cody Miller, and Ellen Vancelette and graduate student Matt Wallace for field and laboratory assistance. We also appreciate reviewers for insightful comments on drafts of this manuscript. This project was supported by grants from USDA-NRCS, RI Agricultural Experiment Station (contribution no. 5426), and NSF EPSCoR Grant No. 0554548.

\section{References}

Addy, K., A. Gold, B. Nowicki, J. McKenna, M. Stolt, and P. Groffman. 2005. Denitrification capacity in a subterranean estuary below a Rhode Island (USA) fringing salt marsh. Estuaries 28:896-908. doi:10.1007/ BF02696018

Anderson, C.J., W.J. Mitsch, and R.W. Nairn. 2005. Temporal and spatial development of surface soil conditions at two created riverine marshes. J. Environ. Qual. 34:2072-2081. doi:10.2134/jeq2005.0168

Baker, B.W., and E.P. Hill. 2003. Beaver (Castor canadensis). In: G.A. Feldhamer, et al., editors, Wild mammals of North America: Biology, management, and conservation. 2nd ed. Johns Hopkins Univ. Press, Baltimore, MD. p. 288-310.

Batson, J.A., Ü. Mander, and W.J. Mitsch. 2012. Denitrification and a nitrogen budget of created riparian wetlands. J. Environ. Qual. 41:2024-2032. doi: $10.2134 /$ jeq2011.0449

Beaulieu, J.J., J.L. Tank, S.K. Hamilton, W.M. Wollheim, R.O. Hall, P.J. Mulholland, B.J. Peterson, L.R. Ashkenas, L.W. Cooper, C.N. Dahm, W.K. Dodds, N.B. Grimm, S.L. Johnson, W.H. McDowell, G.C. Poole, H.M. Valett, C.P. Arango, M.J. Bernot, A.J. Burgin, C.L. Crenshaw, A.M. Helton, L.T. Johnson, J.M. O’Brien, J.D. Potter, R.W. Sheibley, D.J. Sobota, and S.M. Thomas. 2011. Nitrous oxide emission from denitrification in stream and river networks. Proc. Natl. Acad. Sci. U.S.A. 108:214-219.

Blake, G.R., and K. Hartge. 1986. Bulk density. In: A. Klute, editor, Methods of soil analysis. Part 1. 2nd ed. Agron. Monogr. 9. ASA and SSSA, Madison, WI. p. 363-375.

Bledzki, L.A., J.L. Bubier, L.A. Moulton, and T.D. Kyker-Snowman. 2011. Downstream effects of beaver ponds on the water quality of New England first- and second-order streams. Ecohydrology 4:698-707. doi:10.1002/ eco. 163 
Bonnett, S.A.F., M.S.A. Blackwell, R. Leah, V. Cook, M. O'Connor, and E. Maltby. 2013. Temperature response of denitrification rate and greenhouse gas production in agricultural river marginal wetland soils. Geobiology 11:252-267. doi:10.1111/gbi.12032

Brezonik, P.L., and G.F. Lee. 1968. Denitrification as a nitrogen sink in Lake Mendota, Wisconsin. Environ. Sci. Technol. 2:120-125. doi:10.1021/ es60014a003

Burgin, A.J., and S.K. Hamilton. 2007. Have we overemphasized the role of denitrification in aquatic ecosystems? A review of nitrate removal pathways. Front. Ecol. Environ. 5:89-96. doi:10.1890/1540-9295(2007)5[89:HWOTRO]2.0.CO;2

Butler, D.R., and G.P. Malanson. 2005. The geomorphic influences of beaver dams and failures of beaver dams. Geomorphology 71:48-60. doi:10.1016/j. geomorph.2004.08.016

Carlton, R.G., and R.G. Wetzel. 1988. Phosphorus flux from lake sediments: Effect of epipelic algal oxygen production. Limnol. Oceanogr. 33:562570. doi:10.4319/lo.1988.33.4.0562

Colman, B.P., N. Fierer, and J.J. Schimel. 2007. Abiotic nitrate incorporation in soil: Is it real? Biogeochemistry 84:161-169. doi:10.1007/s10533-007-9111-5

Colman, B.P., N. Fierer, and J.P. Schimel. 2008. Abiotic nitrate incorporation, anaerobic microsites, and the ferrous wheel. Biogeochemistry 91:223-227. doi: 10.1007/s10533-008-9281-9

Currie, W.S., K.J. Nadelhoffer, and J.D. Aber. 1999. Soil detrital processes controlling the movement of $15 \mathrm{~N}$ tracers to forest vegetation. Ecol. Appl. 9:87-102.

David, M.B., L.G. Wall, T.V. Royer, and J.L. Tank. 2006. Denitrification and the nitrogen budget of a reservoir in an agricultural landscape. Ecol. Appl. 16:2177-2190. doi:10.1890/1051-0761(2006)016[2177:DATNBO]2. $0 . \mathrm{CO} ; 2$

Davidson, E.A., J. Chorover, and D.B. Dail. 2003. A mechanism of abiotic immobilization of nitrate in forest ecosystems: The ferrous wheel hypothesis. Glob. Change Biol. 9:228-236. doi:10.1046/j.1365-2486.2003.00592.x

Davidson, E.A., J. Chorover, and D.B. Dail. 2008. Iron interference in the quantification of nitrate in soil extracts and its effect on hypothesized abiotic immobilization of nitrate. Biogeochemistry 90:65-73. doi:10.1007/s10533-008-9231-6

Davidson, E.A., S.C. Hart, C.A. Shanks, and M.K. Firestone. 1991. Measuring gross nitrogen mineralization, immobilization, and nitrification by $\mathrm{N}-15$ isotopic pool dilution in intact soil cores. J. Soil Sci. 42:335-349. doi:10.1111/j.1365-2389.1991.tb00413.x

Davidson, E.A., M.B. David, J.N. Galloway, C.L. Goodale, R. Haeuber, J.A. Harrison, R.W. Howarth, D.B. Jaynes, R.R. Lowrance, B.T. Nolan, J.L. Peel, R.W. Pinder, E. Porter, C.S. Snyder, A.R. Townsend, and M.H. Ward. 2012. Excess nitrogen in the U.S. environment: Trends, risks, and solutions. Issues in Ecol. 15:1-16.

Devito, K.J., and P.J. Dillon. 1993. Importance of runoff and winter anoxia to the $\mathrm{P}$ and $\mathrm{N}$ dynamics of a beaver pond. Can. J. Fish. Aquat. Sci. 50:22222234. doi: $10.1139 /$ f93-248

DeStefano, S., K.G. Koenen, C.M. Henner, and J. Strules. 2006. The transition to independence in subadult beavers (Castor canadensis) in an unexploited, exponentially growing population. J. Zool. (Lond.) 269:434-441. doi:10.1111/j.1469-7998.2006.00160.x

Eaton, A.D., L.S. Clesceri, A.E. Greenberg, and M.H. Franson. 1998. Standard methods for the examination of water and wastewater. APHA, AWWA, and WEF. Washington, DC.

Fanning, D.S., and M.B. Fanning. 1989. Soil morphology, genesis, and classification. John Wiley \& Sons, Hoboken, NJ.

Fitzhugh, R.D., G.M. Lovett, and R.T. Venterea. 2003. Biotic and abiotic immobilization of ammonium, nitrite, and nitrate in soils developed under different tree species in the Catskill Mountains, New York, USA. Glob. Change Biol. 9:1591-1601. doi:10.1046/j.1365-2486.2003.00694.x

Fulweiler, R.W., S.W. Nixon, B.A. Buckley, and S.L. Granger. 2007. Reversal of the net dinitrogen gas flux in coastal marine sediments. Nature 448:180182. doi: $10.1038 /$ nature 05963

Galloway, J.N., J.D. Aber, J.W. Erisman, S.P. Seitzinger, R.W. Howarth, E.B. Cowling, and B.J. Cosby. 2003. The nitrogen cascade. Bioscience 53:341356. doi:10.1641/0006-3568(2003)053[0341:TNC]2.0.CO;2

Galloway, J.N., F.J. Dentener, D.G. Capone, E.W. Boyer, R.W. Howarth, S.P. Seitzinger, G.P. Asner, C.C. Cleveland, P.A. Green, E.A. Holland, D.M. Karl, A.F. Michaels, J.H. Porter, A.R. Townsend, and C.J. Vöosmarty. 2004. Nitrogen cycles: Past, present, and future. Biogeochemistry 70:153226. doi: $10.1007 / \mathrm{s} 10533-004-0370-0$

Gibson, P.P., and J.D. Olden. 2014. Ecology, management, and conservation implications of North American beaver (Castor canadensis) in dryland streams. Aquat. Conserv. Mar. Freshwater Ecosyst. 24:391-409. doi:10.1002/aqc.2432
Gold, A.J., W.R. DeRagon, W.M. Sullivan, and J.L. Lemunyon. 1990. Nitratenitrogen losses to groundwater from rural and suburban land uses. J. Soil Water Conserv. 45:305-310.

Gold, A.J., P.M. Groffman, K. Addy, D.Q. Kellogg, M. Stolt, and A.E. Rosenblatt. 2001. Landscape attributes as controls on ground water nitrate removal capacity of riparian zones. J. Am. Water Resour. Assoc. 37:1457-1464. doi:10.1111/j.1752-1688.2001.tb03652.x

Green, L.T. 2009. Quality assurance project plan for the University of Rhode Island Watershed Watch Analytical Laboratory. University of Rhode Island, Kingston.

Groffman, P.M., A.M. Dorsey, and P.M. Mayer. 2005. Nitrogen processing within geomorphic features in urban streams. J. North Am. Benthol. Soc. 24:613-625. doi:10.1899/04-026.1

Groffman, P.M., A.J. Gold, D.Q. Kellogg, and K. Addy. 2002. Mechanisms, rates and assessment of nitrous oxide in groundwater, riparian zones and rivers. In: J. Van Ham, editor, Non $\mathrm{CO}_{2}$ greenhouse gases: Scientific understanding, control options, and policy aspects. Millpress, Rotterdam, the Netherlands. p. 159-166.

Gurnell, A.M. 1998. The hydrogeomorphological effects of beaver dam-building activity. Prog. Phys. Geogr. 22:167-189.

Hammerson, G. 1994. Beaver (Castor canadensis) ecosystem alterations, management and monitoring. Nat. Areas J. 14:44-57.

Han, H., and J.D. Allan. 2008. Estimation of nitrogen inputs to catchments: Comparison of methods and consequences for riverine export prediction. Biogeochemistry 91:177-199. doi:10.1007/s10533-008-9279-3

Hardisky, T. 2011. Beaver management in Pennsylvania. Pennsylvania Game Commission. Harrisburg, PA.

Harrison, J.A., R.J. Maranger, R.B. Alexander, A.E. Giblin, P.-A. Jacinthe, E. Mayorga, S.P. Seitzinger, and W. Wollheim. 2009. The regional and global significance of nitrogen removal in lakes and reservoirs. Biogeochemistry 93:143-157. doi:10.1007/s10533-008-9272-x

Hernandez, M.E., and W.J. Mitsch. 2007. Denitrification potential and organic matter as affected by vegetation community, wetland age, and plant introduction in created wetlands. J. Environ. Qual. 36:333-342. doi:10.2134/jeq2006.0139

Hill, A.R., and T.P. Duval. 2009. Beaver dams along an agricultural stream in southern Ontario, Canada: Their impact on riparian zone hydrology and nitrogen chemistry. Hydrol. Processes 23:1324-1336. doi:10.1002/hyp.7249

Howarth, R.W., G. Billen, D. Swaney, A. Townsend, N. Jaworski, K. Lajtha, J.A. Downing, R. Elmgren, N. Caraco, T. Jordan, F. Berendse, J. Freney, V. Kudeyarov, P. Murdoch, and Z. Zhao-Liang. 1996. Regional nitrogen budgets and riverine $\mathrm{N}$ and $\mathrm{P}$ fluxes for the drainages to the North Atlantic Ocean: Natural and human influences. Biogeochemistry 35:75-139. doi:10.1007/BF02179825

Jensen, P.G., P.D. Curtis, M.E. Lehnert, and D.L. Hamelin. 2001. Habitat and structural factors influencing beaver interference with highway culverts. Wildl. Soc. Bull. 29:654-664.

Kellogg, D.Q., A.J. Gold, S. Cox, K. Addy, and P.V. August. 2010. A geospatial approach for assessing denitrification sinks within lower-order catchments. Ecol. Eng. 36:1596-1606. doi:10.1016/j.ecoleng.2010.02.006

Knowles, R. 1981. Denitrification. In: F.E. Clark, et al., editors, Terrestrial nitrogen cycles, processes, ecosystem strategies and management impacts. Ecological Bulletin 33. Swedish Natural Science Research Council, Stockholm. p. 315-329.

Lazar, J.G., K. Addy, M.K. Welsh, A.J. Gold, and P.M. Groffman. 2014. Resurgent beaver ponds in the northeastern United States: Implications for greenhouse gas emissions. J. Environ. Qual. 43:1844-1852. doi:10.2134/jeq2014.02.0065

Mariotti, A. 1983. Atmospheric nitrogen is a reliable standard for natural ${ }^{15} \mathrm{~N}$ abundance measurements. Nature 303:685-687. doi:10.1038/303685a0

McClain, M.E., E.W. Boyer, C.L. Dent, S.E. Gergel, N.B. Grimm, P.M. Groffman, S.C. Hart, J.W. Harvey, C.A. Johnston, E. Mayorga, W.H. McDowell, and G. Pinay. 2003. Biogeochemical hot spots and hot moments at the interface of terrestrial and aquatic eco- systems. Ecosystems 6:301-312. doi:10.1007/s10021-003-0161-9

Mitsch, W.J., J.W. Day, Jr., J.W. Gilliam, P.M. Groffman, D.L. Hey, G.W. Randall, and N. Wang. 2001. Reducing nitrogen loading to the Gulf of Mexico from the Mississippi River Basin: Strategies to counter a persistent ecological problem: Ecotechnology-the use of natural ecosystems to solve environmental problems-should be a part of efforts to shrink the zone of hypoxia in the Gulf of Mexico. Bioscience 51:373-388. doi:10.1641/0006-3568(2001)051[0373:RNLTTG]2.0.CO;2

Moore, R.B., C.M. Johnston, K.W. Robinson, and J.R. Deacon. 2004. Estimation of total nitrogen and phosphorus in New England streams using spatially referenced regression models. U.S. Geological Survey Scientific Investigations Report 2004-5012. http://pubs.usgs.gov/sir/2004/5012/ SIR2004-5012_report.pdf. 
Mulholland, P.J., A.M. Helton, G.C. Poole, R.O. Hall, S.K. Hamilton, B.J. Peterson, J.L. Tank, L.R. Ashkenas, L.W. Cooper, C.N. Dahm, W.K. Dodds, S.E.G. Findlay, S.V. Gregory, N.B. Grimm, S.L. Johnson, W.H. McDowell, J.L. Meyer, H.M. Valett, J.R. Webster, C.P. Arango, J.L. Beaulieu, M.J. Bernot, A.J. Burgin, C.L. Crenshaw, L.T. Johnson, B.R. Niederlehner, J.M. O’Brien, J.D. Potter, R.W. Sheibley, D.J. Sobota, and S.M. Thomas. 2008. Stream denitrification across biomes and its response to anthropogenic nitrate loading. Nature 452:202-205. doi:10.1038/ nature 06686

Mulvaney, R.L. 1996. Nitrogen: Inorganic Forms. In: D.L. Sparks, editor, Methods of soil analysis. Part 3. Chemical methods. ASA and SSSA, Madison, WI. p. 1123-1184.

Mulvaney, R.L. 2008. Advances in methodology for research on nitrogen transformations in soils. In: J.S. Schepers and W. Raun, editors, Nitrogen in agricultural systems. Agron. Monogr. 49. ASA and SSSA, Madison, WI. p. 437-504.

Nadelhoffer, K.J., M.R. Downs, and B. Fry. 1999. Sinks for ${ }^{15} \mathrm{~N}$-enriched additions to an oak forest and a red pine plantation. Ecol. Appl. 9:72-86. doi:10.1890/1051-0761(1999)009[0072:SFNEAT]2.0.CO;2

Naiman, R., C. Johnston, and J. Kelley. 1988. Alteration of North American streams by beaver. Bioscience 38:753-762. doi:10.2307/1310784

Naiman, R., G. Pinay, C. Johnston, and J. Pastor. 1994. Beaver influences on the long-term biogeochemical characteristics of boreal forest drainage networks. Ecology 75:905-921. doi:10.2307/1939415

Nguyen, L.M. 2000. Organic matter composition, microbial biomass and microbial activity in gravel-bed constructed wetlands treating dairy wastewaters. Ecol. Eng. 16:199-221. doi:10.1016/ S0925-8574(00)00044-6

Nowicki, B.L. 1994. The effect of temperature, oxygen, salinity, and nutrient enrichment on estuarine denitrification rates measured with a modified nitrogen gas flux technique. Estuar. Coast. Shelf Sci. 38:137-156. doi:10.1006/ecss.1994.1009

Nummi, P., and S. Holopainen. 2014. Whole-community facilitation by beaver: Ecosystem engineer increases waterbird diversity. Aquat. Conserv. Mar. Freshwater Ecosyst. 24:623-633. doi:10.1002/aqc.2437

Oakley, S.M., A.J. Gold, and A.J. Oczkowski. 2010. Nitrogen control through decentralized wastewater treatment: Process performance and alternative management strategies. Ecol. Eng. 36:1520-1531. doi:10.1016/j. ecoleng.2010.04.030

Oviatt, C.A., and A.J. Gold. 2005. Nitrate in Coastal Waters. In: T.M. Addiscott, editor, Nitrate, agriculture, and the environment. Oxford Univ. Press, New York. p. 127-147.

Pollock, M.M., M. Heim, and D. Werner. 2003. Hydrologic and geomorphic effects of beaver dams and their influence on fishes. Am. Fish. Soc. Symp. 37:213-233.

Pollock, M.M., G.R. Pess, and T.J. Beechie. 2004. The importance of beaver ponds to Coho Salmon production in the Stillaguamish River Basin, Washington, USA. N. Am. J. Fish. Manage. 24:749-760. doi:10.1577/ M03-156.1

Saunders, D.L., and J. Kalff. 2001. Nitrogen retention in wetlands lakes and rivers. Hydrobiologia 443:205-212. doi:10.1023/A:1017506914063

Schlesinger, W.H. 2009. On the fate of anthropogenic nitrogen. Proc. Natl. Acad. Sci. U.S.A. 106:203-208.

Scott, J.T., M.J. McCarthy, W.S. Gardner, and R.D. Doyle. 2008. Denitrification, dissimilatory reduction to ammonium, and nitrogen fixation along a nitrate concentration gradient in a created freshwater wetland. Biogeochemistry 87:99-111. doi: 10.1007/s10533-007-9171-6

Seitzinger, S.P. 1988. Denitrification in freshwater and coastal marine ecosystems: Ecological and geochemical significance. Limnol. Oceanogr. 33:702-724. doi:10.4319/lo.1988.33.4_part_2.0702
Seitzinger, S., J.A. Harrison, J.K. Böhlke, A.F. Bouwman, R. Lowrance, B. Peterson, C. Tobias, and G.V. Drecht. 2006. Denitrification across landscapes and waterscapes: A synthesis. Ecol. Appl. 16:2064-2090. doi:10.1890/1051-0761(2006)016[2064:DALAWA]2.0.CO;2

Seitzinger, S., S. Nixon, M.E. Pilson, and S. Burke. 1980. Denitrification and $\mathrm{N}_{2} \mathrm{O}$ production in near-shore marine sediments. Geochim. Cosmochim. Acta 44:1853-1860. doi:10.1016/0016-7037(80)90234-3

Sigman, D.M., M.A. Altabet, R. Michener, D.C. McCorkle, B. Fry, and R.M. Holmes. 1997. Natural abundance-level measurement of the nitrogen isotopic composition of oceanic nitrate: An adaptation of the ammonia diffusion method. Mar. Chem. 57:227-242. doi:10.1016/ S0304-4203(97)00009-1

Song, K., H. Kang, L. Zhang, and W.J. Mitsch. 2012. Seasonal and spatial variations of denitrification and denitrifying bacterial community structure in created riverine wetlands. Ecol. Eng. 38:130-134. doi:10.1016/j. ecoleng.2011.09.008

Sorensen, P., and E.S. Jensen. 1991. Sequential diffusion of ammonium and nitrate from soil extracts to a polytetrafluoroethylene trap for ${ }^{15} \mathrm{~N}$ determination. Anal. Chim. Acta 252:201-203. doi:10.1016/0003-2670(91)87215-S

Stark, J.M., and S.C. Hart. 1996. Diffusion technique for preparing salt solutions, Kjeldahl digests, and persulfate digests for nitrogen-15 analysis. Soil Sci. Soc. Am. J. 60:1846-1855. doi:10.2136/sssaj1996.03615995006000060033x

Stark, J.M., and S.C. Hart. 1997. High rates of nitrification and nitrate turnover in undisturbed coniferous forests. Nature 385:61-64. doi:10.1038/385061a0

StatSoft, Inc. 2013. Electronic statistics textbook. StatSoft, Tulsa, OK. http:// www.statsoft.com/textbook/ (accessed 11 July 2014).

Tiedje, J.M. 1982. Denitrification. In: A.L. Page, et al., editors, Methods of soil analysis. Part 2. 2nd ed. Agron. Monogr, Madison, WI. p. 1011-1025.

Tietema, A., B.A. Emmett, P. Gundersen, O.J. Kjønaas, and C.J. Koopmans. 1998. The fate of ${ }^{15} \mathrm{~N}$-labelled nitrogen deposition in coniferous forest ecosystems. For. Ecol. Manage. 101:19-27. doi:10.1016/S0378-1127(97)00123-0

Tietz, A., A. Kirschner, G. Langergraber, K. Sleytr, and R. Haberl. 2007. Characterization of microbial biocoenosis in vertical subsurface flow constructed wetlands. Sci. Total Environ. 380:163-172. doi:10.1016/j. scitotenv.2006.11.034

Turner, R.E., and N.N. Rabalais. 1994. Coastal eutrophication near the Mississippi river delta. Nature 368:619-621. doi:10.1038/368619a0

Univ. of Rhode Island. 2013. Rhode Island GIS data distribution system. Univ. Rhode Island, Geospatial Extension Program, Environmental Data Center. http://www.edc.uri.edu/rigis (accessed 6 Mar. 2014).

Vecherskiy, M.V., V.V. Korotaeva, N.V. Kostina, T.G. Dobrovol'skaya, and M.M. Umarov. 2011. Biological activities of beaver landscape soils. Moscow Univ. Soil Sci. Bull. 66:175-179. doi:10.3103/S0147687411040089

Weyhenmeyer, C.E. 1999. Methane emissions from beaver ponds: Rates, patterns, and transport mechanisms. Global Biogeochem. Cycles 13:1079-1090. doi:10.1029/1999GB900047

Whitfield, C.J., H.M. Baulch, K.P. Chun, and C.J. Westbrook. 2015. Beavermediated methane emission: The effects of population growth in Eurasia and the Americas. Ambio 44:7-15. doi:10.1007/s13280-014-0575-y

Witt, C., J.L. Gaunt, C.C. Galicia, J.C. Ottow, and H.U. Neue. 2000. A rapid chloroform-fumigation extraction method for measuring soil microbial biomass carbon and nitrogen in flooded rice soils. Biol. Fertil. Soils 30:510-519. doi: $10.1007 / \mathrm{s} 003740050030$

Wrage, N., G.L. Velthof, M.L. Van Beusichem, and O. Oenema. 2001. Role of nitrifier denitrification in the production of nitrous oxide. Soil Biol. Biochem. 33:1723-1732. doi:10.1016/S0038-0717(01)00096-7

Xue, Y., D.A. Kovacic, M.B. David, L.E. Gentry, R.L. Mulvaney, and C.W. Lindau. 1999. In situ measurements of denitrification in constructed wetlands. J. Environ. Qual. 28:263-269. doi:10.2134/ jeq1999.00472425002800010032x 